\title{
Electrical Properties and Infrared Studies of Heated Mica Sheets
}

\author{
M. Dawy \\ Physical Chemistry Department, \\ National Research Center, Dokki, Cairo, Egypt.
}

\begin{abstract}
Dielectric constant $(\dot{\varepsilon})$, dielectric loss $\left(\varepsilon^{\prime \prime}\right)$ and (tan $\delta$ ) have been measured for heated Mica sheets at different temperatures $\left(200-900^{\circ} \mathrm{C}\right)$ for 2 hours in the frequency range $\left(0.1-100 \mathrm{KH}_{Z}\right)$. It has been found that the dielectric constant and dielectric loss are nearly stable till $600^{\circ} \mathrm{C}$ but showing an increase at 800 and $900^{\circ} \mathrm{C}$. The dielectric loss and tan $\delta$ show maximum 800 and $900^{\circ} \mathrm{C}$. The activation energy values of dielectric relaxation have been calculated for mica sheets for the latter temperatures. It was observed that the activation energy values go on increasing with increasing heating temperature from $800^{\circ} \mathrm{C}$ to $900^{\circ} \mathrm{C}$. The resistivity of mica sheets was studied also as a function of temperature in the range $\left(30-70^{\circ} \mathrm{C}\right)$ for the samples heated at $800^{\circ} \mathrm{C}$ and $900^{\circ} \mathrm{C}$ over frequency range [0.1-100 $\left.\mathrm{KH}_{\mathrm{z}}\right]$. It was found that the resistivity increases with temperature and decreases with frequency. The resistivity at $900^{\circ} \mathrm{C}$ is higher than $800^{\circ} \mathrm{C}$ overall the range used. Infrared spectra were studied to link the influence of the structure of heated mica with their thermal behavior.
\end{abstract}




\section{Introduction:}

Mica is a generic name given to a family of hydrous potassuim aluminum silicates having similar physical properties. Some of the familiar known mica are muscovite, phologopite, biotite, lepidolite and vermiculite (although the last is not commercially classified as a mica). Only the first two have commercial demand in rubber and plastics application. The major markets for dry and wet ground mica are for joint cement, roofing, well drilling mud, and paints. The plastic and rubber industries consume less than $10 \%$ of the total U.S. mica produced [1-3].

The muscovite structure is dioctahedral, with one out of three octahedral positions being open. The phlogopite structure is tri-octahedral with all octahedral positions being filled. In other words, the replacement of the two $\mathrm{Al}^{+3}$ ions is neutralized by three ions of $\mathrm{Mg}^{+2}$ and/or $\mathrm{Fe}^{+2}$. Isomorphous substitution within the silica-alumina frame work, as well as with bridging cation, can be readily accomplished. Much isomorphous substitution work with synthetic fluorophlogopites has been published [4\&5].

The abundance, the relatively low cost of mica and the inherently good electrical properties of this mineral are factors, which have maintained merest in the use of mica in various applications. A mica-alumina combination is selected for the insulating system at temperatures higher than $500^{\circ} \mathrm{C}$. The aging condition was to apply 1.5 k.v.as voltage in nitrogen atmosphere at $550^{\circ} \mathrm{C}$ [6].

A mica-alumna-silicon combination was selected for insulation system at higher temperatures. Using this insulation system, an aging pretest was performed in order to give information about its stability. Several well established tests produce have implemented to better understand the electrical and thermal aging mechanisms of mica-based stator insulating system. The measurement of dielectric properties, weight loss and observable deterioration pattern of an insulation sample at several isotherms is used to establish are liable operating temperature limit. An emergency temperature limit is determined by short-term exposure to high temperatures and detection of insulation delimitation by acoustic spectrum analysis of specimen resonant frequencies. Test results are compared between mature system and proposed system. This procedure is used to establish operating limitations for rewound equipment as well as estimate the remaining service life of existing machines [7].

Infrared absorption spectra can provide information on the structure of the oxide glasses [8]. The vibrational spectra can be used to identify glasses or specific groups, which are present in it [9\&10]. DTA, TG and DTG investigated 
several isomorphic groups of different types of mica. The combination of thermal and IR- spectra of hydroxyl analyses permits to link the Order-Disorder data with thermal properties of mica [11].

The aim of this work is to study the effect of heat treatment till $900^{\circ} \mathrm{C}$ on the dielectric properties and electrical resistivity of natural Mica. Infrared absorption spectra of natural mica sheets were studied also to link the influence of the structure of mica with their thermal behavior.

\section{Experimental:}

Natural mica sheets, from Waddy El-Alaky, East Desert, Egypt,were prepared for measurements as discs of $12 \mathrm{~mm}$ diameter and $1 \mathrm{~mm}$ thickness. The prepared samples were thermally heat-treated at different temperatures (200$900^{\circ} \mathrm{C}$ ) for 2 hours. An AG-4311 B RCL-meter (Ando-Japan) was used to measure the Dielectric properties (dielectric constant $\dot{\varepsilon}$, dielectric loss $\dot{\varepsilon}$ and $\tan \delta$ ). The resistivity measurements of the treated samples were measured in the frequency range (0.1-100 $\mathrm{KH}_{\mathrm{z}}$ ). Infrared spectra were carried out using Jasco Forier Transformation Infrared (FT/IR) 300E Spectrophotometer. The samples were measured as Potassium Bromide $(\mathrm{KBr})$ discs covering the range $\left(100-4000 \mathrm{~cm}^{-1}\right)$.

\section{Spectrographic Elemental Analysis of Mica:}

Natural mica sheet were exposed to semiquantative spectrographic analysis. Mica content in percent are listed in Table (1). Forty mg of the mica was mixed with an equal amount of spec pure graphite in a clean agate mortar. The samples were burn according to the following specifications:

Spectrograph: Zeiss Jena medium quartz prism spectrograph type, Q-24.

Slit width: $14 \mu$.

Lens diaphragm: $3.2 \mathrm{~mm}$.

Electrode: RWI spec pure graphite electrode.

Excitation: 220 V, D.C. are anode excitation.

Current: 9 amperes.

Plate: ORWO yellow extrahard $9 \times 24 \mathrm{~cm}$.

Exposure time: o/90 sec. Followed by arck for another $60 \mathrm{sec}$.

Processing: $5 \mathrm{~min}$. in freshly prepared ORWDI developer and

10 min. in hypo fixer.

Carl Zeiss spectrum projector by examined the spectrum

Comparison with spectrum was spec standards. 
Table (1): Semiquantitative spectrographic analysis of mica sample.

\begin{tabular}{|l|l|}
\hline \multicolumn{1}{|c|}{ Elements Present } & \multicolumn{1}{c|}{ Approximate Quantity } \\
\hline $\mathrm{Al}, \mathrm{Fe} \& \mathrm{Si}$ & Major $10 \%$ \\
$\mathrm{Mg}, \mathrm{Mn}, \& \mathrm{Na}$ & Minor $1-10 \%$ \\
$\mathrm{Ca}, \mathrm{Ga}, \mathrm{K}, \& \mathrm{Ti}$ & Trace $0.1-1 \%$ \\
$\mathrm{Ba}, \mathrm{Cu}, \mathrm{V}, \& \mathrm{Zn}$ & Faint trace $0.01-0.1 \%$ \\
$\mathrm{Be}, \mathrm{Ni}, \mathrm{Pb}, \& \mathrm{Sn}$ & Very faint trace $0.001-0.01 \%$ \\
\hline
\end{tabular}

\section{Results and Discussion:}

\section{I- Dielectric Properties:}

\section{I-1 Effect of Thermal Heating:}

Mica sheets under investigation were subjected to thermal heating for 2 hours at $200,400,600,800$ and $900^{\circ} \mathrm{C}$. The dielectric properties as dielectric constant $\dot{\varepsilon}$, dielectric loss $\dot{\varepsilon}$ and tan $\delta$ after each stage of heating were measured in the frequency range $\left(0.1-100 \mathrm{KH}_{\mathrm{Z}}\right)$. The results obtained are shown in Fig. (1). It can be noticed that the dielectric constant $\dot{\varepsilon}$ increases with rising temperature. This can be attributed to the increase in the mobility and ease of rotation of molecule resulting from the decrease in the dipole-dipole interactions. Also, it can be noticed gradual decrease in dielectric constant as the frequency of the applied field increased. The dielectric dispersion occurs specially at high frequencies. This decrease of $\varepsilon^{\prime \prime}$ with increasing frequency can be explained by the lag of the molecules behind the alterations of the applied electric field. The tendency of change after the heating process was clarified to be caused by a decrease of organic component in the insulation which remained due to incomplete burning. Effects on the dielectric properties can be concluded as follows:

1- The dielectric constant $\varepsilon$ for mica sheet are unaffected by thermal heating till $600^{\circ} \mathrm{C}$ in this range frequency. But, the dielectric constant at 800 and $900^{\circ} \mathrm{C}$ increased to reach $\dot{\varepsilon}_{800}=40>\dot{\varepsilon}_{900}=22$ at $\mathrm{f}=100 \mathrm{~Hz}$.

2- The dielectric loss $\varepsilon$ increases, gradually from 200 to $800^{\circ} \mathrm{C}$ and then decrease in $900^{\circ} \mathrm{C}$.

3- $\tan \delta$ of mica samples is very low and stable after heating temperatures from $200-600^{\circ} \mathrm{C}$ and overall the frequency range used. At $800^{\circ} \mathrm{C}$ and $900^{\circ} \mathrm{C}$ $\tan \delta$ increases showing maximum values (tanó $=0.4$ and 0.8 ) for samples heated at $900^{\circ} \mathrm{C}$ and $800^{\circ} \mathrm{C}$ respectively.

Previous notices indicate that, the dielectric properties for heated sample below $600^{\circ} \mathrm{C}$ showed some stability or resistance to thermal heating process. While, the stability of the samples heated at $800^{\circ} \mathrm{C}$ and $900^{\circ} \mathrm{C}$ fall down showing increase in the dielectric properties. Thus, these samples were chosen to study briefly. The stability occurred to the sample till $600^{\circ} \mathrm{C}$ may be arises from the scattering of the conducting electron by lattice defects due to 
vacancies interstitial in the structure. As the thermal heating increased to $800^{\circ} \mathrm{C}$, the concentration of the induced defect is expected to cease or fall. Vacancies and interstitial recombine or vacancies migration to the surface. Eventually, migration becomes very slow or cease. Then further heating to $900^{\circ} \mathrm{C}$ will lead to corresponding reduction of the concentration of defects and vacancies.
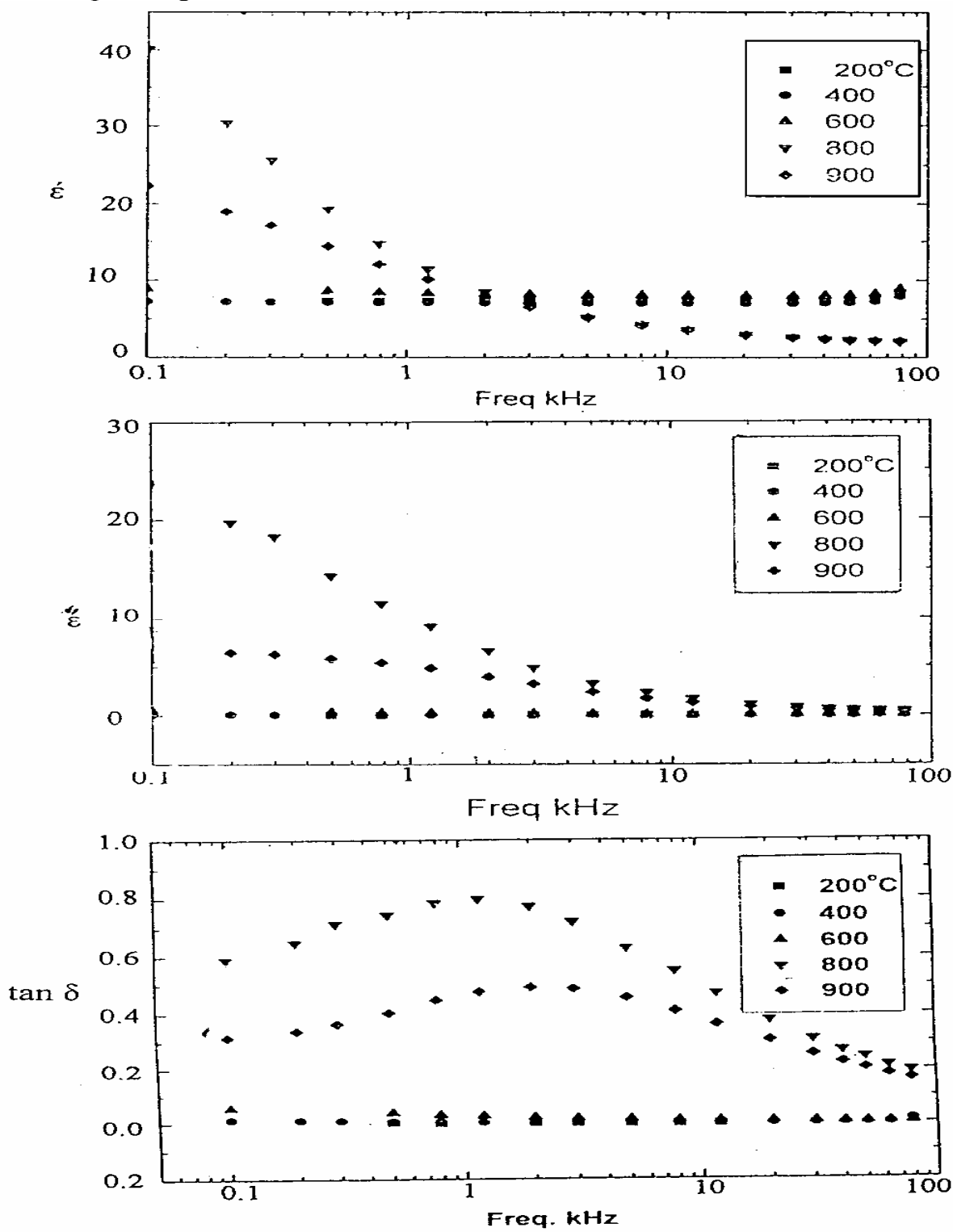

Fig. (1): Variation of the dielectric const. $\dot{\varepsilon}$, dielectric loss $\varepsilon^{\prime \prime}$ and $\tan \delta$ with frequency for mica sheets different heating temperatures. 


\section{2 - Effect of Temperature:}

Mica samples heated at $800^{\circ} \mathrm{C}$ and $900^{\circ} \mathrm{C}$ were chosen to study the dependence of the dielectric properties on temperature and frequencies. The dielectric properties $\dot{\varepsilon}, \varepsilon^{\prime \prime}$, and tan $\delta$ of chosen samples at different temperatures and frequencies are shown in Fig. (2\&3). It can be noticed that the dielectric constant $\varepsilon$ decreases by increasing each of frequency and temperature. The decrease in $\dot{\varepsilon}$ at higher temperature may be due to the thermal agitation, which will not allow the dipoles to be oriented. Moreover, this lowering is observed clearly at lower frequencies where the effect of space charge polarization can be felt [12]. At higher frequency, the real part of dielectric constant changes little with frequency, and the imaginary part is small. The dependence of the dielectric loss $\varepsilon$ " on temperature for selected samples at fixed frequencies showed a loss peak at lower frequencies, and $\dot{\varepsilon}$ decreases with increasing frequency in the rang of the loss. The increase in loss at lower frequencies probably results from the DC resistivity of the sample.

Tan $\delta$ - frequency plot showed loss maximum. Samples heated at $800^{\circ} \mathrm{C}$ has higher values of $\tan \delta$ than that heated at $900^{\circ} \mathrm{C}$. Its position shifts to lower frequency as increasing temperature. Maximum loss of $\tan \delta$ uprising due to dc conductance and increase interference by the conductivity loss at higher temperature.

Generally, there are four primary mechanisms for glass loss spectrum in order of increasing frequency, (1) d.c. conduction ions, (2) ionic relaxation loss refers to ions migrating limited distances and not to rotation of dipoles, (3) Deformation loss, due to structural ionic dipoles (such as Si-O) and (4) Vibrational loss of the ions themselves[13]. Relaxation process is regarded as the jumping of a molecule from one equilibrium position to another over a potential energy barrier.The dipole molecule needs a certain amount of energy (activation energy) to overcome the potential energy barrier separating these two mean equilibrium positions.

To calculate the apparent activation energy for these samples, the logarithm of the frequency corresponding to $f$ maximum was plotted against the reciprocal of the absolute temperature the apparent activation energy was calculated using the equation:

$$
\tau=A \exp [-(\Delta H / R T)
$$

where $\tau=1 / 2 \pi f_{m}$ is the relaxation time at the frequency of maximum loss, $R$ is the gas constant and $T$ is the absolute temperature. Relaxation is pictured as the jumping of molecule from one equilibrium position to another. It is assumed that the process of molecular rotation requires an activation energy sufficient to overcome the energy barriers separating the two main equilibrium positions. The relaxation times, the activation enthalpies and the entropy changes of the dielectric relaxation are given in the Table (2). It can be noticed that, increasing heating temperature from $800^{\circ} \mathrm{C}$ to $900^{\circ} \mathrm{C}$ the rotation of dipoles is less easy this certainly enhance the activation energies. 

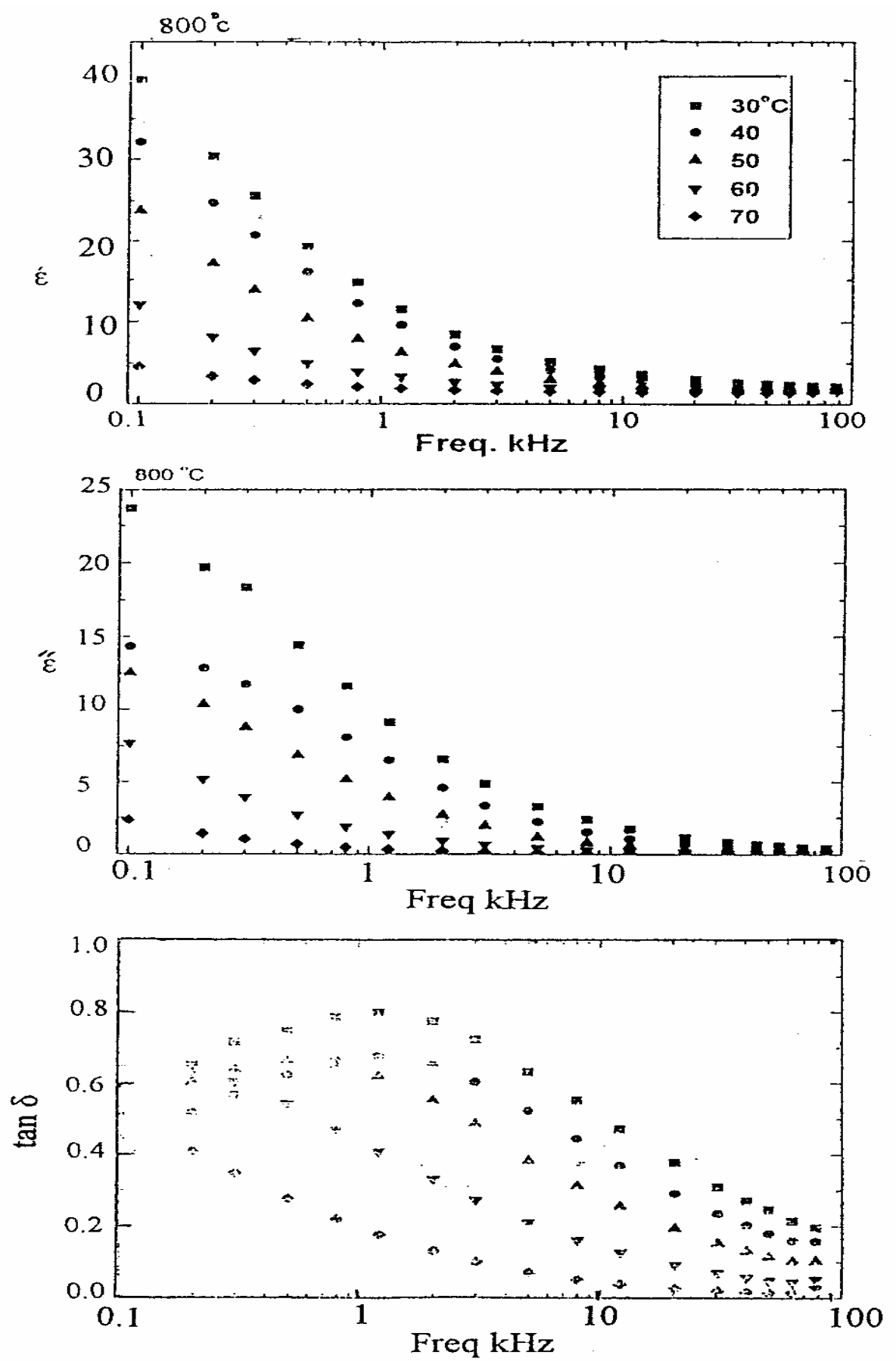

Fig. (2): Variation of dielectric constant $\dot{\varepsilon}$, dielectric loss $\varepsilon^{\prime \prime}$ and $\tan \delta$ for mica sheet heated at $800^{\circ} \mathrm{C}$ at different temperature. 

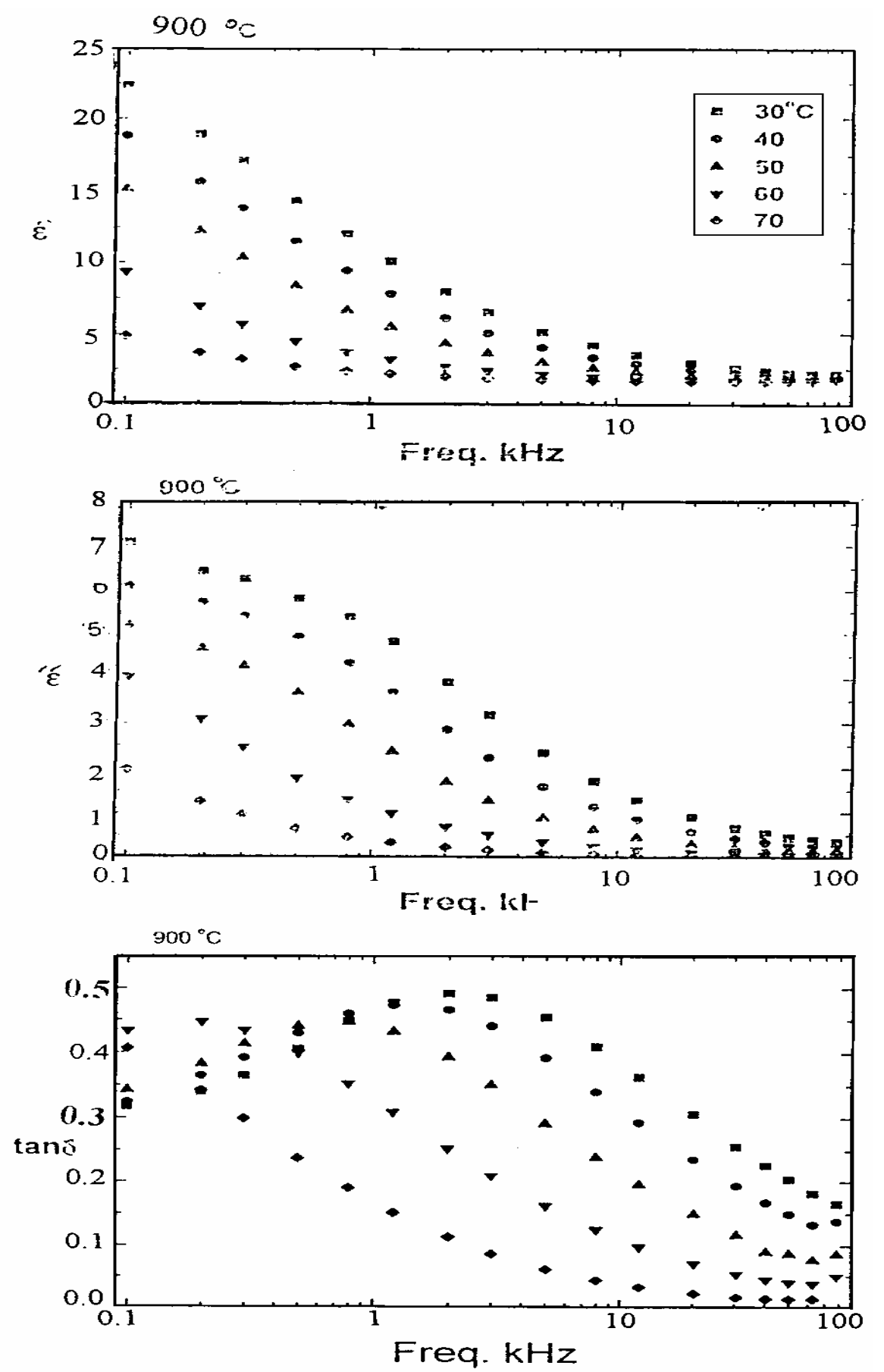

Fig. (3): Variation of dieletric const. $\dot{\varepsilon}$, dielectric loss $\varepsilon^{\prime \prime}$ and $\tan \delta$ for mica sheet heated at $900^{\circ} \mathrm{C}$. 
Table (2): The apparent relaxation times $\tau$, the activation enthalpies $\Delta \mathrm{H}$, and $\Delta \mathrm{S}$ Entropy of dielectric relaxation for mica samples heated at $800^{\circ} \mathrm{C}$ and $900^{\circ} \mathrm{C}$.

\begin{tabular}{|c|c|c|c|c|c|c|}
\hline $\begin{array}{c}\text { Sample } \\
\text { Type. }\end{array}$ & \multicolumn{3}{|c|}{ Mica $\mathbf{8 0 0}^{\circ} \mathrm{C}$} & \multicolumn{3}{c|}{ Mica 900 ${ }^{\mathbf{0}} \mathrm{C}$} \\
\hline Temp. $\left({ }^{\circ} \mathrm{C}\right)$ & $\begin{array}{c}\tau \times 10^{-3} \\
(\mathrm{~S})\end{array}$ & $\begin{array}{c}\Delta \mathrm{H} \\
(\mathrm{Kcal} / \mathrm{mole})\end{array}$ & $\begin{array}{c}\Delta \mathrm{S} \\
(\mathrm{Kcal} / \mathrm{mole})\end{array}$ & $\begin{array}{c}\tau \times 10^{-3} \\
(\mathrm{~S})\end{array}$ & $\begin{array}{c}\Delta \mathrm{H} \\
(\mathrm{Kcal} / \mathrm{mole})\end{array}$ & $\begin{array}{c}\Delta \mathrm{S} \\
(\mathrm{Kcal} / \mathrm{mole})\end{array}$ \\
\hline 40 & 1.22488 & & & 0.758265 & & \\
50 & 1.3266 & 13.72676 & 13.713 & 1.592356 & 18.28629 & 18.276 \\
60 & 3.1847 & & & 7.961783 & & \\
70 & 7.9617 & & & 15.92356 & & \\
\hline
\end{tabular}

\section{II- Electrical Resistivity of Mica:}

The resistivity-temperature relationship for mica sheets heated at $800^{\circ} \mathrm{Cand} 900^{\circ} \mathrm{C}$ in the frequency range $\left(0.1-100 \mathrm{KH}_{\mathrm{z}}\right)$ is shown in Fig. (4). It can be noticed that the resistivity increases with increasing temperature from $30^{\circ} \mathrm{C}$ to $70^{\circ} \mathrm{C}$. Also, the sample heated at $900^{\circ} \mathrm{C}$ has higher values of resistivity than that heated $800^{\circ} \mathrm{C}$. The difference in resistivity between the two samples decreases as the frequency increase. This figure showed also that the resistivity decreases gradually with increasing frequency from $0.2-78 \mathrm{KH}_{\mathrm{z}}$.

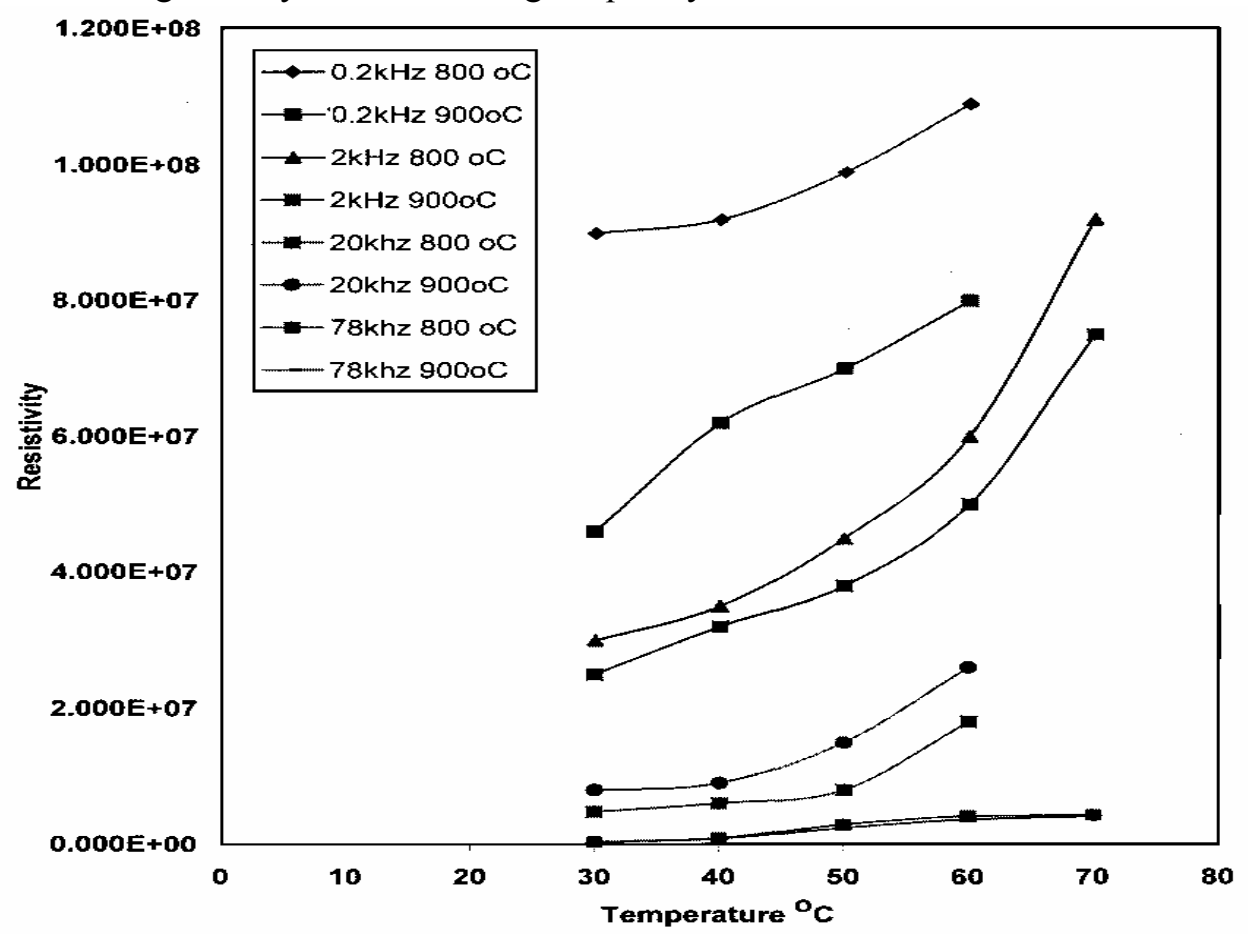

Fig. (4): Variation of resistivity of mica sheet heated at $800^{\circ} \mathrm{C}$ and $900{ }^{\circ} \mathrm{C}$ with temperature at different frequencies. 
The above result can be interpreted as the resistivity of a metal arises from the scattering of the conduction electron by static lattice defects such as vacancies and the thermal scatters which are created by the thermal motion of atoms or electrons. Mica heated at $900^{\circ} \mathrm{C}$ has fewer defects than mica at $800^{\circ} \mathrm{C}$ as a result of recombination of vacancies and or migration to the surface.

AC-conductivity $\left(\sigma_{\mathrm{ac}}\right)$ values are calculated from dielectric measurements using the following expression [14].

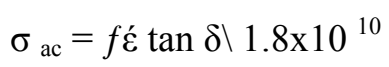

A representative plot of $\log \sigma_{\mathrm{ac}}$ versus frequency $\log \mathrm{f}\left(\right.$ at $\left.300^{\circ} \mathrm{K}\right)$ and for Mica heated 800 and Mica $900^{\circ} \mathrm{C}$ are given in Fig. (5). The nearly linear dependence of AC-conductivity with frequency accounts for the electronic conduction via a hopping process [15]. Also, the relation:

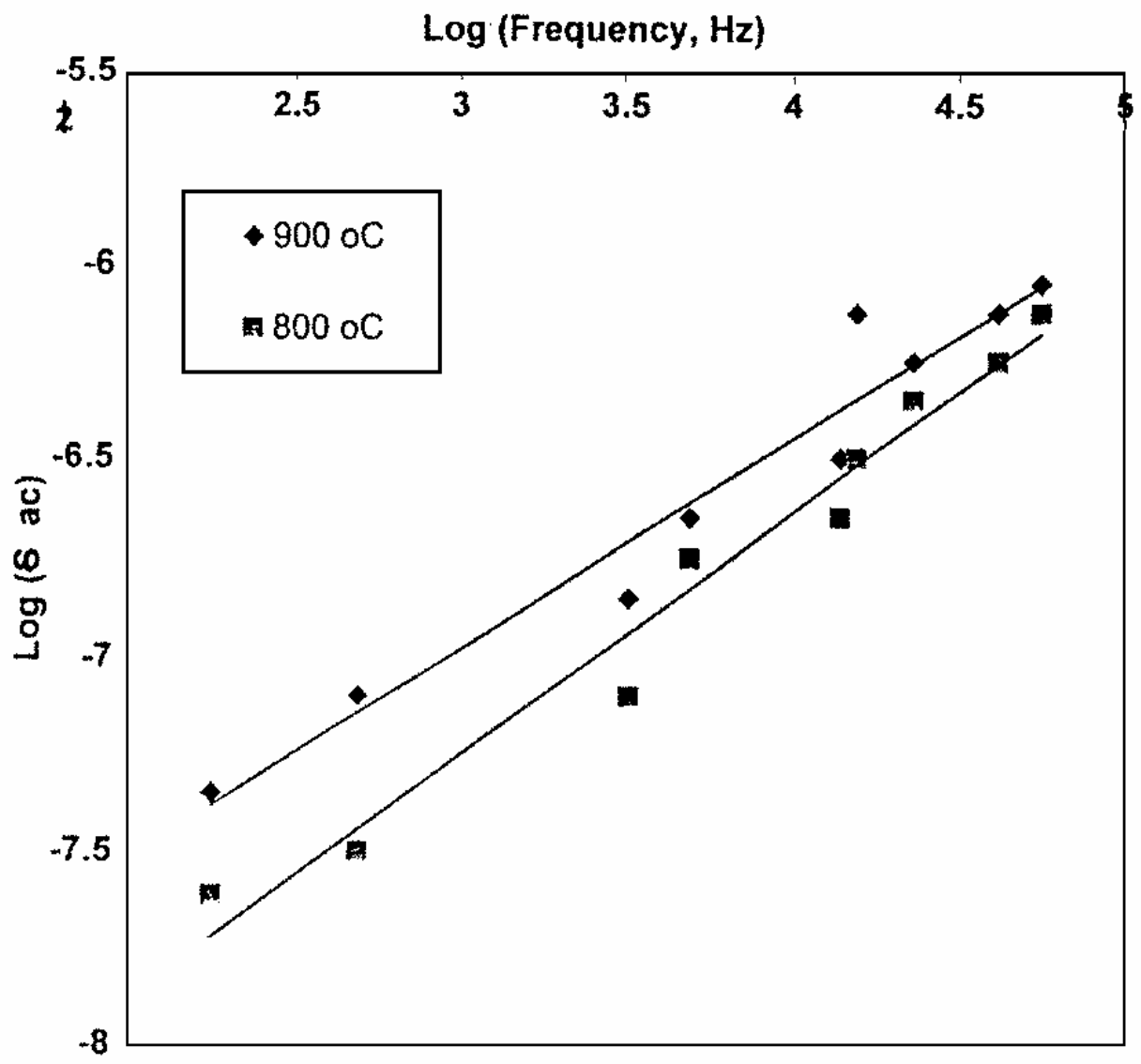

Fig. (5): Variation of $\log \sigma_{\mathrm{ac}}$ versus frequency $\log \mathrm{f}$.

$$
\sigma_{\text {ac }} \alpha \mathrm{f}^{\mathrm{n}}
$$


where $n$ lies between $0.5>n>1$ characterize the electronic conduction via hopping process. In the present study $\mathrm{n}$ equal 0.6 and 0.8 for mica heated at $800^{\circ} \mathrm{C}$ and $900^{\circ} \mathrm{C}$ respectively.

\section{III-IR Spectra}

The infrared spectra of heated mica sheet at 400,600800 and $900^{\circ} \mathrm{C}$ are shown in Fig. (6). Comparing the spectra at different heating temperature is nearly the same except the following:

1- Decrease in the intensity of $\mathrm{OH}-$ bending band at $1537 \mathrm{~cm}^{-1}$ and $\mathrm{OH}-\mathrm{st}$ at $3430 \mathrm{~cm}^{-1}$ is illustrated as a result of heating and disappearance of the last band at 800 and $900^{\circ} \mathrm{C}$.

2- Also, the IR bands of Si-0-Si and M-O-Si bending at 400 and $700 \mathrm{~cm}^{-1}$ are slightly sharpened and decrease in transmission percent.

3- No pronounced shift to higher or lower frequency of the characteristic strong bands of $\mathrm{SiO}_{4}$ at 455,775 and $1050 \mathrm{~cm}^{-1}$ was observed.

4- The band at nearly $2923-\mathrm{cm}^{-1}$ characterizes C-H aliphatic compound decreases in intensity with increasing temperature.

Table (3): Effect of heat treatments for $2 \mathrm{hr}$ on the infrared absorption bands of Mica sheets.

\begin{tabular}{|c|c|c|c|c|c|}
\hline \multicolumn{5}{|c|}{$\begin{array}{l}\text { Frequency in } \mathrm{cm}^{-1} \\
\left.\text { Heat treatment (Temperature }{ }^{\circ} \mathrm{C}\right)\end{array}$} & \multirow[t]{2}{*}{$\begin{array}{c}\text { Assignment } \\
\text { (Approximate Description) }\end{array}$} \\
\hline 200 & 400 & 600 & 800 & 900 & \\
\hline 405 & 400 & 400 & 400 & 401 & Si-O-Si band. \\
\hline 500 & 499 & 490 & 490 & 480 & Si-O-Si band. \\
\hline 510 & 510 & 510 & 510 & 551 & Si-O-M \\
\hline 700 & 700 & 700 & 711 & 709 & B-O-Si band.or B-O-B band \\
\hline 1014 & 1008 & 1008 & 1008 & 1008 & Si-O stretching \\
\hline 1400 & & & & & M-O stretching \\
\hline 1600 & 1600 & 1637 & 1637 & & H-O-H Bending \\
\hline 2923 & 2995 & 2998 & 2998 & $\begin{array}{l}2998 \\
3400\end{array}$ & $\mathrm{C}-\mathrm{H}$ aliphatic \\
\hline 3480 & 3460 & 3460 & 3432 & 3448 & O-H stretching \\
\hline
\end{tabular}



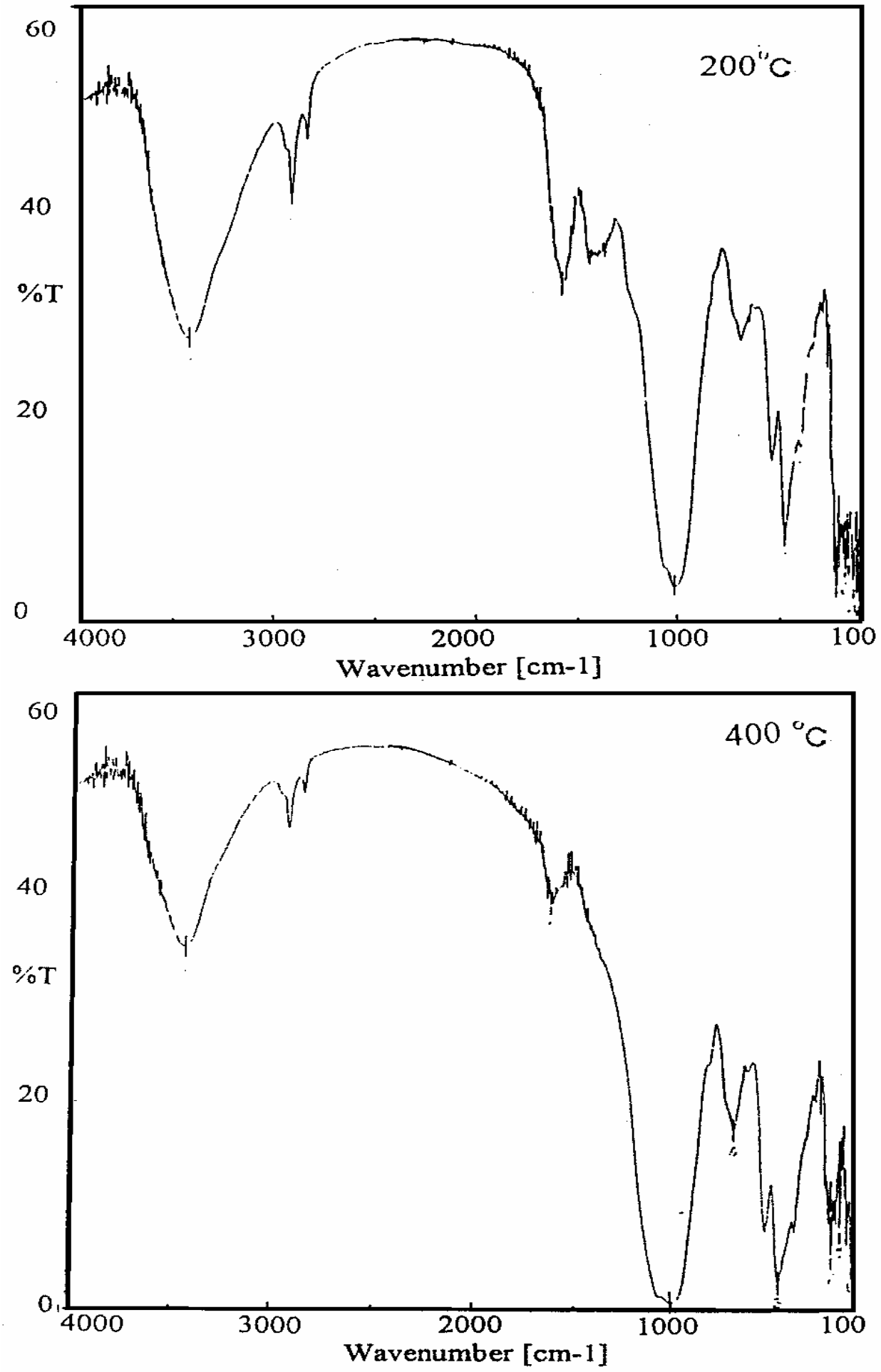

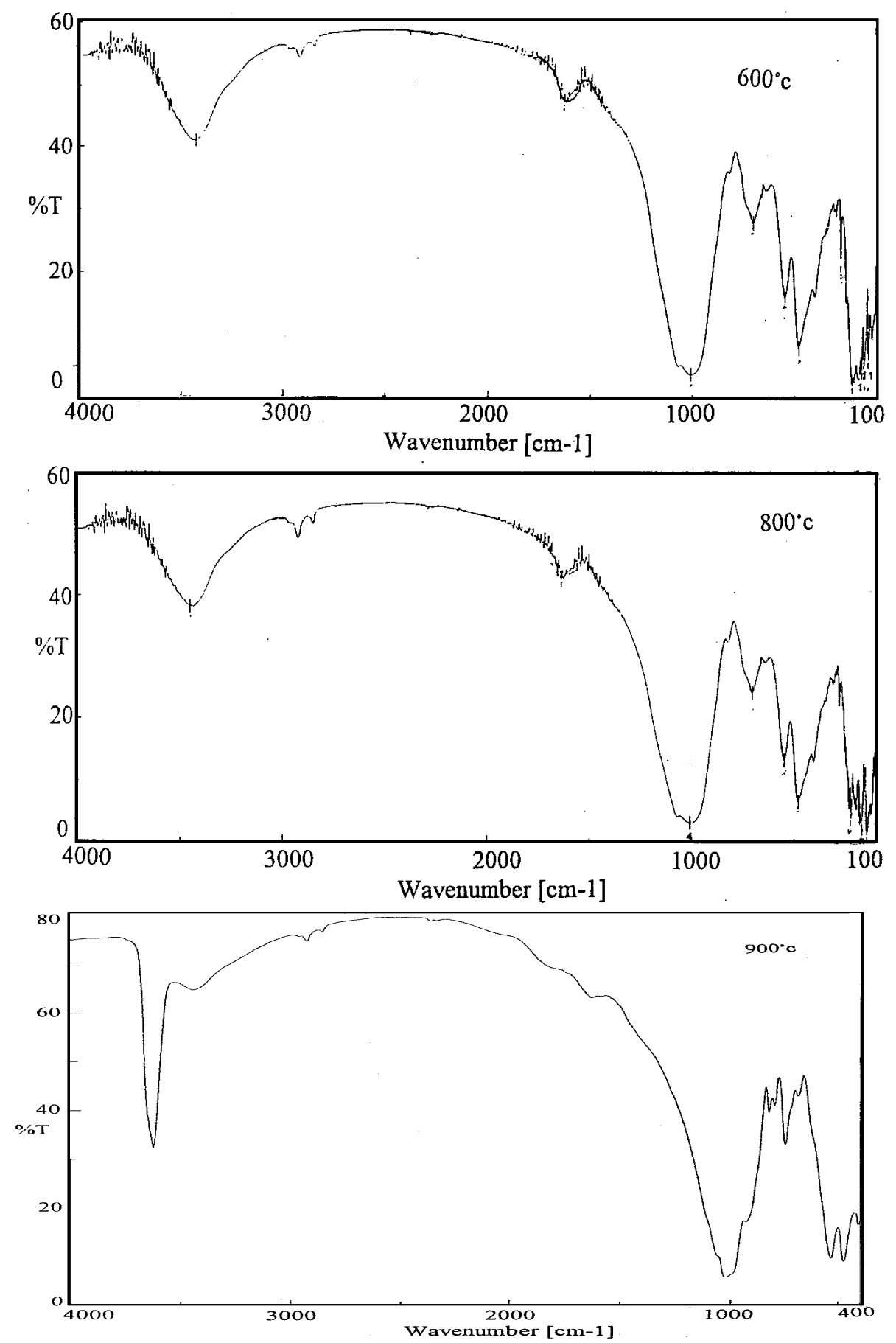

Fig. (6): IR spectra of mica sheet at different thermal heating temperatures. 
Effect of heat treatment for 2 hours in the temperature range $200-900^{\circ} \mathrm{C}$ on the infrared absorption spectra of mica sheet are shown in Table (3). The characteristic bands of $\mathrm{SiO}_{4}$ tetrahedral units were between $400-485 \mathrm{~cm}^{-1}$ (Si-O-Si) bending [16], 675-775 $\mathrm{cm}^{-1}$ (M-O-Si) stretching [17] and $1040-1050 \mathrm{~cm}^{1}(\mathrm{Si}-\mathrm{O})$ stretching [18]. There is no frequency shift in the positions of these bands in temperature range $200-600^{\circ} \mathrm{C}$, but the shift occurred at 800 and $900^{\circ} \mathrm{C}$ due to destruction. The absorbency of these bands, were increased to $800^{\circ} \mathrm{C}$ then decrease at $900^{\circ} \mathrm{C}$ as shown in Fig. (7). The absorbency of the infrared bands at $1637 \mathrm{Cm}^{-1}(\mathrm{H}-\mathrm{OH})$ bending due to the water absorbed decreased mainly after 800 to $900^{\circ} \mathrm{C}$, but the band at $1650 \mathrm{Cm}^{-1}$ diminished. The band at $3480 \mathrm{~cm}^{-1}$ of $(\mathrm{O}-\mathrm{H})$ stretching vibration band decrease at $900^{\circ} \mathrm{C}$ and sharpened.

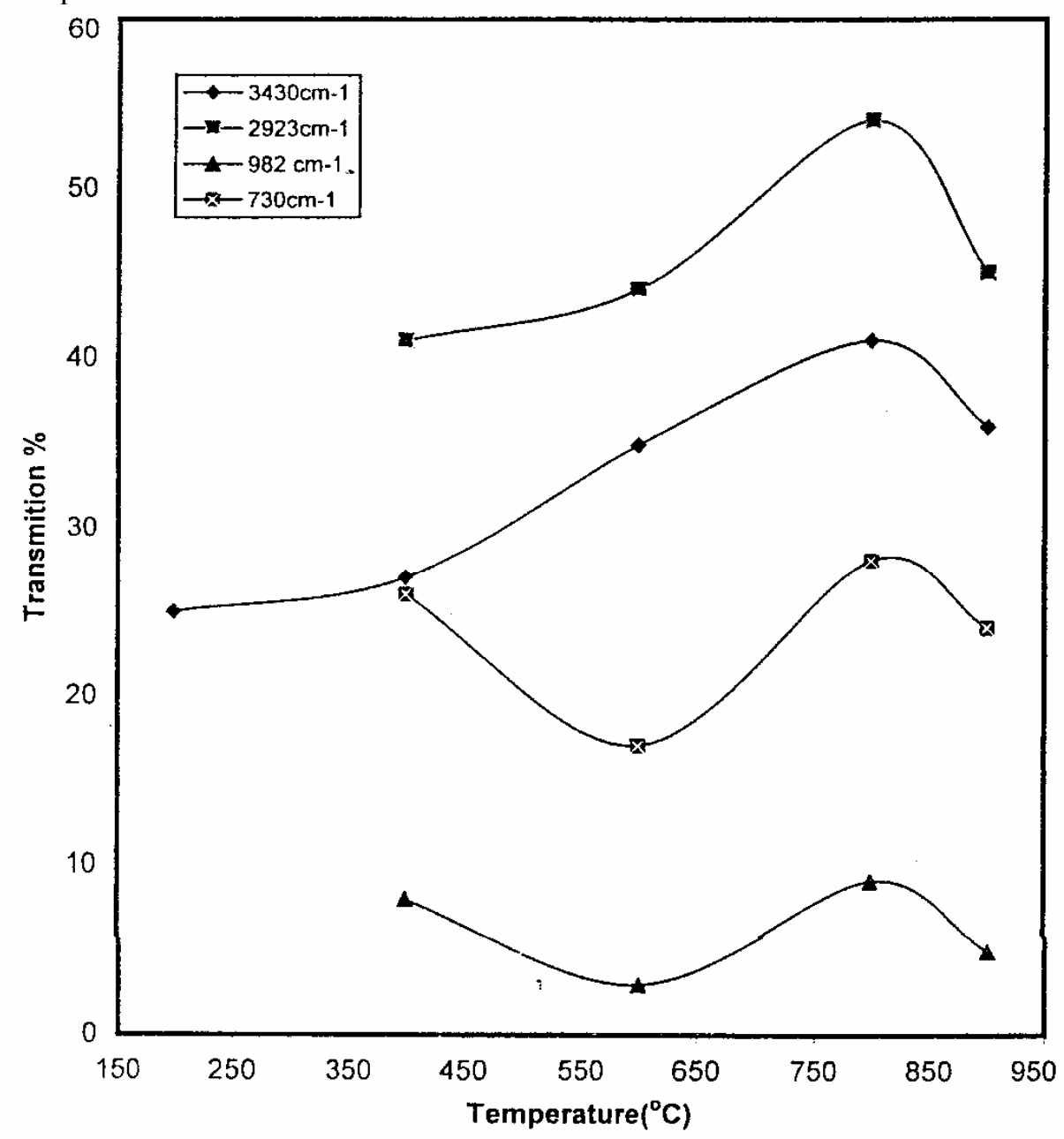

Fig. (7): Effect of thermal heating on the intensity of transimision of mica sheet. 
Mica is a naturally laminated composite of flakes or platelets. The properties of mica vary greatly from one source to another, however many of the variation are not critical in resin composites. Silicate materials as mica have alternating structure of the oxygen and silicon atoms in covalent bonding forming tetrahedral units. Lower oxygen atoms have all the shared electron pairs available to hold adjacent sheets of the structure together. There are two major commercial categories of natural mica, Moscovite $\left[\mathrm{AL}_{2}(\mathrm{OH})_{2} \mathrm{AlSi}_{3} \mathrm{O}_{10}\right]$ and Phlogopite similar in composition $\left[\mathrm{K}_{2} \mathrm{Al}_{4}\left(\mathrm{AL}_{2} \mathrm{Si}_{6} \mathrm{O}_{20}\right](\mathrm{OH})_{4}\right.$. This natural mica is related to mixture of the two types the molecular structure in layer system, each layer consists of a pesudo-octahederal gibbsite plane chemically bonded by bridging oxygen and hydroxyl groups to two tetrahedral silica planes. This two dimensional layer is negatively charged and is held to adjacent layers by positive potassium ions. The potassium ions are in 12-fold coordination interaction with 6-atom from each layer. This ionic interaction is weak because of impurities replacing many potassium ions in natural mica.

Several processes have been occurred on heating layer silicates such as mica as dehydroxylation, mica lattice destruction, destruction of the network, partial melting of material formation of a new phase etc. There is also a correlation between mica composition and product of its thermal distruction [11]. An amorphous phase was present in the final product of all the mica. There is a possibility of isomorphic substitution in octahederal position by several cations, mainly $\mathrm{Mg}, \mathrm{Fe}^{2+}, \mathrm{Al}^{3+}, \mathrm{Fe}^{3+}, \mathrm{Li}$ and $\mathrm{F}, \mathrm{O}^{2-}$ in hydroxyl position. One of the three octahedral positions of mica may also be vacant, therefore there in a complicated system of solid solution although not necessarily a continuous one. According to Vedder and Willkins[19] after static heating at $500-600^{\circ} \mathrm{C}$ the units with vacancies disappear. It seems that the sequence of unit cell dehydroxylation is as follows; (1) units of $\mathrm{Fe}^{3+}$ only; (2) units of the $\mathrm{Fe}^{3+}$ and $\mathrm{Fe}^{2+}$ combinations; (3) units of the $\mathrm{Fe}^{2+}$ only; (4) units of the $\mathrm{Mg}, \mathrm{Fe}^{3+}$ and $\mathrm{Fe}^{2+}$ combinations; (5) units of the $\mathrm{MgMg}$ and $\mathrm{Fe}^{2+}$ and $\mathrm{Fe}^{3+}$ combinations; (6) units of the $\mathrm{Mg}$ only. The influence of the fine structure of mica will interpret their thermal behavior in IR and Dielectric properties due to phase change occurred after $800^{\circ} \mathrm{C}$.

\section{Conclusion:}

IR spectra showed no frequency shift in the position of the bands in the temperature range $200-600^{\circ} \mathrm{C}$, but small shift occur in the temperature range 800 $900^{\circ} \mathrm{C}$.The absorbency the bands increased till $800^{\circ} \mathrm{C}$, then decreased at $900^{\circ} \mathrm{C}$, indicating phase transition at $900^{\circ} \mathrm{C}$. The absorbencies of the infrared bands at (1600-1637 $\mathrm{Cm}^{-1} \mathrm{H}-\mathrm{OH}$ bending) due to absorbed water decreased mainly till $800^{\circ} \mathrm{C}$ and diminished at $900^{\circ} \mathrm{C}$. These results confirmed with the stability of the dielectric properties till $600^{\circ} \mathrm{C}$ while there is change in the electrical behavior after heating at 800 and $900^{\circ} \mathrm{C}$.

The linear dependence of AC-conductivity with frequency accounts for the electronic conduction via hopping process. 


\section{References:}

1. G. Clark, Mica. A Review of world developments. Indust. Min. pp. 27-50. June (1983)

2. M. Xanthos, Mica Filler/ reinforcement in flake form. Plast. Compound. pp. 19-29, July (1983)

3. N. Allbee. Update; Mica Fillers / reinforcements Plast, Compound, November (1984)

4. R.A. Hatch, R.A. Humphreg, W. Eitel, and J.E. Omeforo, U.S. Bur Mines Rep. Invest 5337, (1957).

5. H.R. Shell, U.S. Bur. Mines Rep. Invest. 5667, (1960)

6. M. Ishida, Y. Ikeda, N. Naohara, Electrical Engineering in Japan, 116 (3), 14 (1996).

7. J.E. Temperly, D.A. Klinect, R.B. Malter, Proceedings of American Power Conference v57-2, 1995. Illinois Inst. of Technology, Chicago, IL, USA, p.889-903, (1995).

8. A.S. Barker, and A.I. Sievers, Rev. Mod. Phys. 47, 1 (1975)

9. R. Condrate, "Introduction to Glass Science", Vol. 3, Plenum press, New Yourk, USA, P. 101 (1972).

10. W.B. Furukawa, and White, Twelfth International Cong. On glass, Albuquerque, New mexico, USA, (1980)

11. I..L. Lapides, J. Thermal Analysis 42, 197 (1994).

12. Rashmi G. K., Narula and Pillai P.K.C., J. Macromol. Sci. Phys. B 26(2), 185 (1987).

13. J.M. Stevels, "The Electrical Properties of Glass", Handbuch der Physik. 20, 350 (1957).

14. B. Tareev, "Physics of Dielectric Materials MIR", Moscow, 1979.

15. A. Kuerkowski, R. Zielinski, J. Phys. D. Appl. Phys. 15, 1765 (1982).

16. M.H. Manghnani, J.R. Ferraro, and L. Basile, J. Appl. Spectroscopy 28(3), 256 (1974).

17. E.R. Lippincolt, C.E. Weir, and E.N. Bunting, J. Res. Nat. Bur Stand. (61), 16 (1958).

18. E.M.A. Kalil, Ceramurgia Technologia Ceramica, 3, 140 (1977).

19. W. Vedder, and R.W.T. Wilkins, Amer. Miner. 54, 482 (1969). 